\title{
WHY COSTUMERS HAVE THE INTENTION TO REPURCHASE AT COFFEE SHOPS IN BOGOR? EXPLAINING THE ROLE OF SOCIAL MEDIA MARKETING, DINING ATMOSPHERE, AND RELATIONSHIP MARKETING
}

\author{
Alim Setiawan Slamet ${ }^{*}$, , Caesavela Almas*), Dikky Indrawan ${ }^{* *}$ \\ ${ }^{*}$ Department of Management, Faculty of Economics and Management, IPB University \\ Jl. Kamper, IPB Dramaga Campus 16680 Bogor, Indonesia \\ ${ }^{* *}$ School of Business, IPB University \\ Jl. Pajajaran Bogor 16151, Indonesia
}

\begin{abstract}
This study aims to determine the impact of relationship marketing, social media marketing, and dining atmosphere on customer trust and repurchase intention. This study was conducted by surveying 407 customers who frequently visited Ngopi Doeloe, Popolo Coffee, Ranin Coffee House, Starbucks Coffee, Jco Donuts \& Coffee, and The Coffee Bean \& Tea Leaf, and Structural Equation Model (SEM) was used to test the research hypotheses. The findings supported the hypotheses that relationship marketing and social media marketing positively affected repurchase intention and customer trust. Relationship marketing had the greatest influence on customer trust in local coffee shops. In contrast, the dining atmosphere did not affect repurchase intention.
\end{abstract}

Keywords: customer trust, dining atmosphere, relationship marketing, repurchase intention,social media marketing

Abstrak: Penelitian ini bertujuan mengetahui pengaruh relationship marketing, social media marketing, dan dining atmosphere terhadap costumer trust dan repurchase intention. Penelitian ini dilakukan dengan cara survey terhadap 407 pelanggan yang sering mengunjungi Ngopi Doeloe, Popolo Coffee, Ranin Coffee House, Starbucks Coffee, Jco Donuts \& Coffee, dan The Coffee Bean \& Tea Leaf, menggunakan Structural Equation Model (SEM) untuk menguji hipotesis penelitian. Hasil penelitian sesuai dengan hipotesis yang dibuat yaitu relationship marketing dan social media marketing mempunyai pengaruh positif terhadap repurchase intention dan costumer trust. Relationship marketing mempunyai pengaruh terbesar pada costumer trust di coffee shop lokal. Sedangkan dining atmosphere tidak mempunyai pengaruh terhadap repurchase intention.

Kata kunci: customer trust, dining atmosphere, relationship marketing, repurchase intention, social media marketing

${ }^{1}$ Corresponding author:

Email: alimss@apps.ipb.ac.id 


\section{INTRODUCTION}

For centuries, the habit of drinking coffee has been inextricably linked to human life. Coffee consumption is expected to rise in the future as a result of cultural factors, economic conditions, changes in drinking tastes (presentation of various flavours), perceptions of coffee's health benefits, and lifestyle changes (Torga and Spers, 2020). Drinking coffee has many roles today, not only as a source of enjoyment but also as a medium to communicate with the public; many people are beginning to like drinking coffee as social media usage increase (Ashbeck, 2020). The growing popularity of coffee and changes in people's lifestyles have increased the number of coffee shops in Indonesia. Because urban residents have a more consumerist attitude than rural residents, the development of this modern coffee shop can be seen in many large city centres. One of them is the city of Bogor, which is one of the cities in West Java with a relatively high population density that continues to grow year after year.

As the world's population grows, so does the demand for coffee. From 2014 to 2015, there was an increase in the number of coffee shops in Bogor (from 51 shops to 56 shops). The steady economic growth rate in the Bogor city area has enticed global coffee shop brands such as Starbucks Coffee, The Coffee Bean and Tea Leaf, JCo, and others to open many franchises in Bogor. The increasing growth of the global coffee shop has also resulted in the growth of local coffee shops that are equally appealing to the concept of cafes and the quality of their coffee products, such as Popolo Coffee, Ngopi Doeloe, and Rumah Kopi Ranin. Coffee shop growth has resulted in competition among coffee shops, giving consumers the freedom to choose. As a result, it is critical to strengthen its competitive position while maintaining consumer repurchase intentions (Jang et al. 2015).

Continuous repurchase intent leads to customer loyalty, which leads to increased company profits. Consumer loyalty cannot be created without consistent repurchase intention (Chinomona and Dubihlela, 2014). As a result, businesses must increase customer repurchase intent as the first step in developing customer loyalty. Companies can influence customers' attitudes toward the products/ services offered by establishing relationship marketing with customers, preventing customers from switching to other brands. Ndubisi (2017) uses four dimensions of relationship marketing: trust, commitment, communication, and conflict handling. Building a good relationship with customers can increase the customer's desire to buy again, resulting in undeniable long-term loyalty.

In addition to relationship marketing, one of the strategies for retaining customers and obtaining long-term repurchase intent is to create a pleasant dining environment (cafe atmosphere). According to Levy (2001), store atmosphere/dining atmosphere is defined as "the design of the environment through visual communication, lighting, colours, music, and scents to stimulate perception and response emotional customer and ultimately influence customer behaviour in purchasing goods." Because store atmosphere/ dining atmosphere is important in forming consumer loyalty, mixed marketing should be considered to affect consumer loyalty. Furthermore, in the formation of consumer loyalty, consumers respond not only to the company's goods or services but also to the convenience created by the company. An outlet's identity can be communicated to customers through decoration or, more broadly, through its atmosphere (Kotler, 2008). A pleasant atmosphere is also an important factor for customers when deciding whether or not to visit a particular cafe. People like to visit unique cafes because the concept and location are in line with the community's lifestyle (Oldenburg, 1999; Waxman, 2006).

Customers have been directly influenced by the dining atmosphere to promote the coffee shops and their products. This is accomplished by posting photos on social media of the cafe's atmosphere, interior or exterior, which according to the community is unique, comfortable, or vice versa. According to Phillips and Noble (2007), traditional mass media is becoming less effective as a marketing tool with the rise of social media platforms. Nawaz et al. (2015) concluded that social media users' decisions are influenced by criticism and information shared by other users after researching the impact of social media on the decision-making process. Rina et al. (2014) suggest that social media marketing has a significant effect on purchase intention.

Meanwhile, Husein and Toor (2017) discovered that social network marketing is significantly related to consumer purchasing interest. Furthermore, according to Fannani et al. (2020), purchase intention can be 
increased by social media influence. Social media can develop customer knowledge about products/ information based on customer attention, interest, and search factors.

Many people believe that repurchase intention is strongly related to customer trust, based on theories and the findings of previous studies (Wen and Yazdanifard, 2014). Sheth et al. (2004) define trust as a willingness to rely on others' ability, integrity, and motivation to act following the needs and interests that have been agreed upon implicitly or explicitly. Trust is a critical component in the development of high-quality business relationships. Trust has been viewed as a catalyst in various transactions between sellers and buyers for marketers to achieve the desired level of consumer satisfaction (Yousafzai et al. 2003). Unjaya and Santoso (2015) discovered that the trust variable has the most powerful influence on repurchase intention. Customers' repurchase intentions were linked with the trust variable in this study.

Although there has been previous research on repurchase intention, studies on the impact of relationship marketing, dining atmosphere, and social media marketing on coffee shop consumers' customer trust and repurchase intention are still not widely carried out, especially in Indonesia. This study aims to evaluate these variables simultaneously through a structural equation modelling approach. In addition, a comprehensive study of the comparison of consumer behaviour is needed to support the sustainability of local coffee shops such as Ngopi Doeloe, Popolo Coffee, and Ranin Coffee House with global coffee shop companies to compete with global coffee shops. Such as JCo Donuts \& Coffee, Starbucks Coffee, and The Coffee Bean \& Tea Leaf. Their outlets are spread across various shopping centres throughout Indonesia.

\section{METHODS}

The study was carried out in Bogor City in April of this year. The samples in this study were all respondents who had visited the coffee shops. The researcher employed a sampling technique known as convenience sampling to determine the number of respondents. A total of 407 Bogor residents participated in this study. The conceptual framework was based on relationship marketing, social media and dining atmosphere on customer trust and repurchase intention. The research framework consists of variables can be seen in Figure 1.

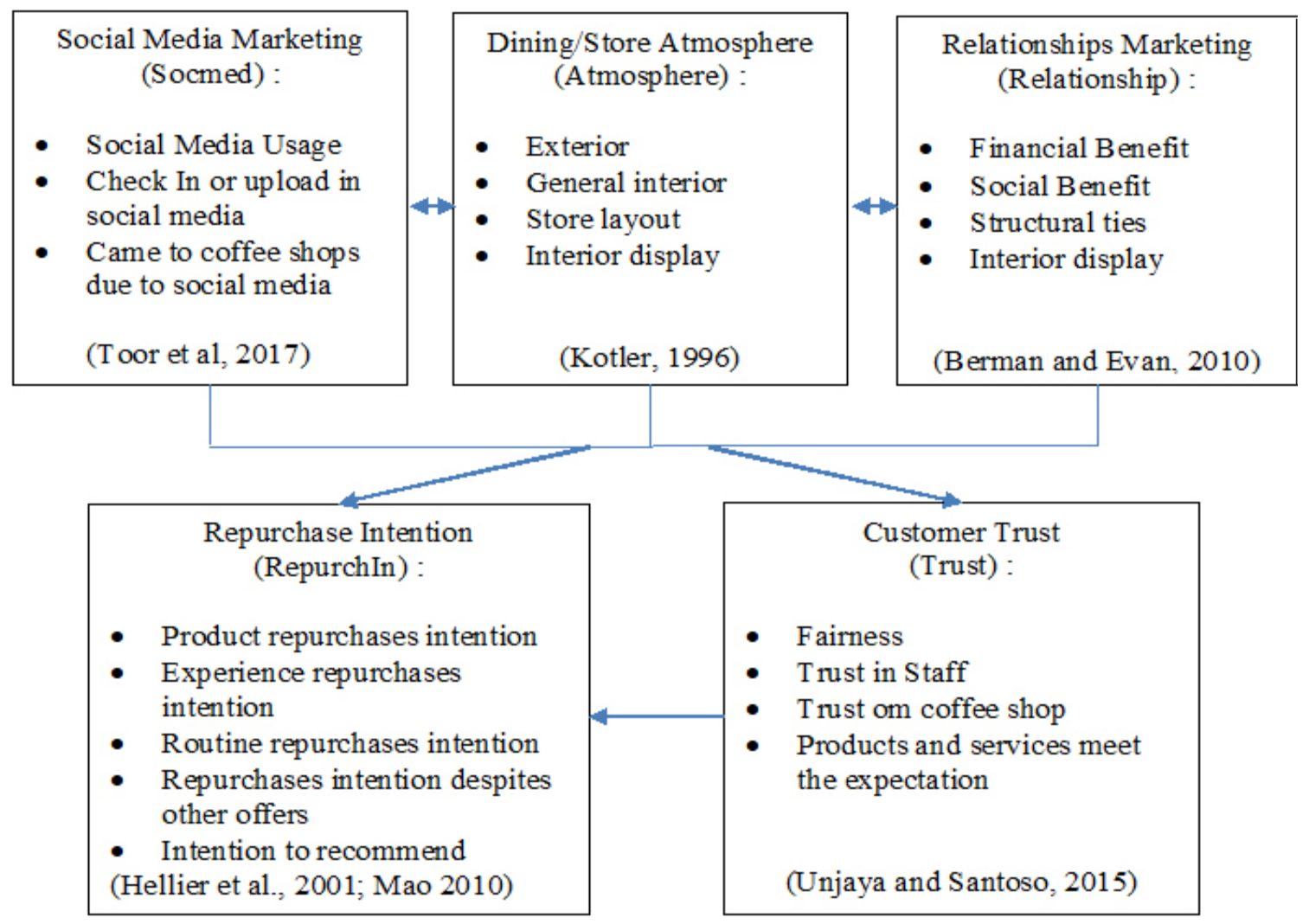

Figure 1. Research framework 
The questionnaire was distributed both online and through direct distribution via the Google Forms site. The distribution of online questionnaires was carried out to reach a large number of respondents quickly and make the filling process easier for respondents. The study used a Likert scale with a score of 1 to 5 to measure the variables.

The primary data analysis was performed using structural equation modelling (SEM). The collected data was initially tested for validity and reliability using the SPSS (Statistical Package Social Science) for the Mac version 23 program. The authors then used descriptive analysis to examine the characteristics of the respondents. Respondents were divided into groups based on age, gender, last education, occupation, monthly income, frequency of visits to the coffee shop, type of coffee shop preferred, expenses for a single visit to the coffee shop. The AMOS 20 software analysis tool was used to perform SEM analysis to conclude. The tool was used to examine the pattern of relationships between latent variables and indicators, latent variables with one another, and direct measurement errors. It discussed the impact of relationship marketing, social media marketing, and dining environment on customer trust and repurchase intention.

According to Sugiyono (2013), a formulation of a problem can be known answered by creating a hypothesis. The answer is a temporary answer to the problem. It is supported by Kerlinger (2006), who said that the hypothesis relates two or more variables. Hypotheses test is significant when the statistic result is in critical value (a value where $\mathrm{H} 0$ is rejected); otherwise, if not significant, $\mathrm{H} 0$ is accepted. These hypotheses have been made to see the influence of relationship marketing, dining atmosphere, and social media marketing on customer trust and repurchase intention from the customer of Ngopi Doeloe, Popolo Coffee, Rumah Kopi Ranin, Starbucks Coffee, The Coffee Bean \& Tea Leaf and JCo Donuts \& Coffee in simultaneous and partially. The hypotheses from this study are :

H1 : It is expected that Relationship Marketing has a directly significant influence on repurchase intention from every coffee shop customer.

H2 : It is expected that Dining Atmosphere has a directly significant influence to repurchase intention from every coffee shop costumers.
H3 : It is expected that Social Media Marketing has a directly significant influence to repurchase intention from every coffee shop customer.

H4 : It is expected that Relationship Marketing has a significant influence on customer trust from every coffee shop customer.

H5 : It is expected that Dining Atmosphere has a significant influence on customer trust from every coffee shop costumers.

H6 : It is expected that Social Media Marketing has a significant influence on customer trust from every coffee shop customer.

H7 : It is expected that Customer Trust has a significant influence to repurchase intention from every coffee shop customer.

\section{RESULTS}

\section{Consumer profile and purchasing patterns}

The lifestyle of drinking coffee is now changing, as indicated in Table 1. Most consumers who come to the coffee shop are between 21 and 30 years old (83\%). This is because people in this age group prefer to eat out and congregate in coffee shops. At the same time, people in this age range are more mobile and prefer to congregate in places like coffee shops with related relatives. In terms of gender distribution, 46.4 percent of respondents were male, while the remaining 53.6 percent were female. The majority of respondents in this study were female. According to the findings of research and interviews, female respondents prefer to meet at coffee shops or hang out with their friends because coffee shops are considered comfortable and suitable for their needs.

According to the results of the calculation of the distribution of respondents by occupation, students have the highest percentage of 36.9 percent from a total of 407 respondents, where the student status has a tendency to visit coffee shops to just gather or do college assignments. As a result, both local and global coffee shops should focus more on marketing that is appealing to students, such as applying discount promos for students by showing student cards, and so on, which will undoubtedly attract the interest of the majority of customers, who students dominate. Furthermore, 39.3 percent of respondents earn less than IDR3,000,000 in the income category. It can be concluded that respondents earning less than IDR3,000,000 prefer 
to visit coffee shops; this is related to the results of the work category calculation, where the majority of the respondents' jobs are students with no income or salary. 43 percent of the total 407 respondents prefer local coffee shops, while the remaining 57 percent prefer global coffee shops.

Furthermore, as shown in Table 2, the researchers processed cross-tabulation data based on the type of coffee shop chosen. Regarding expenditure, the average one-time visit to a coffee shop, most respondents spent IDR50,000 - IDR150,000 per visit, both locally and globally. And, like the majority of global coffee shop respondents (65 percent), 50 percent of local coffee shop respondents visited coffee shops less than twice per week. It is possible to conclude that the frequency of weekly arrivals and the average expenditure of one coffee shop visit for local and global coffee shop respondents have a balanced distribution.

The most selected local coffee shop respondents in the category of the main factors that make respondents visit coffee shops were a comfortable atmosphere (44\%), good coffee quality (32\%), and easy-to-reach locations (11\%). Meanwhile, the top three ranking factors in global coffee shops were the main reasons for respondents to visit a coffee shop: a comfortable atmosphere, good coffee quality, and a well-known brand/image. Most respondents at local and global coffee shops choose reasons to hang out/relax and socialize with relatives as the main reason for visiting coffee shops.

Table 1. Consumer characteristics

\begin{tabular}{|c|c|c|c|}
\hline Characteristics & Groups & Respondent & Percentage $(\%)$ \\
\hline \multirow[t]{4}{*}{ Age } & $<20$ Years & 38 & 9.3 \\
\hline & $21-30$ Years & 338 & 83.0 \\
\hline & $31-40$ Years & 19 & 4.6 \\
\hline & $>41$ Years & 12 & 2.9 \\
\hline \multirow[t]{2}{*}{ Gender } & Man & 189 & 46.4 \\
\hline & Woman & 218 & 53.6 \\
\hline \multirow[t]{3}{*}{ Education } & High School/Equivalent & 53 & 13.0 \\
\hline & Diploma & 150 & 36.9 \\
\hline & $\mathrm{S} 1$ / S2 / S3 & 204 & 50.1 \\
\hline \multirow[t]{6}{*}{ Profession } & Student/College Student & 150 & 36.9 \\
\hline & entrepreneur & 66 & 16.2 \\
\hline & Professional & 82 & 20.1 \\
\hline & Government Employees (PNS/POLRI/TNI) & 27 & 6.6 \\
\hline & Housewife & 14 & 3.4 \\
\hline & Others & 68 & 16.7 \\
\hline \multirow[t]{5}{*}{ Income } & $<$ IDR 3,000,000 & 160 & 39.3 \\
\hline & IDR 3,000,000 - IDR 5,000,000 & 124 & 30.5 \\
\hline & IDR 5,000,000 - IDR 7,000,000 & 59 & 14.5 \\
\hline & IDR 7,000,000 - IDR 10,000,000 & 36 & 8.8 \\
\hline & $>$ IDR $10,000,000$ & 28 & 6.9 \\
\hline \multirow{2}{*}{$\begin{array}{l}\text { The most preferred } \\
\text { coffee shop }\end{array}$} & Coffee Shop Local (Popolo, Doeloe Coffee, Ranin Coffee House) & 175 & 43.0 \\
\hline & Coffee Shop Global (Starbucks, The Coffee Bean \& Tea Leaf, JCo) & 232 & 57.0 \\
\hline \multirow{7}{*}{$\begin{array}{l}\text { The most visited } \\
\text { Coffee Shop }\end{array}$} & Starbucks Coffee & 155 & 38.1 \\
\hline & The Coffee Bean \& Tea Leaf & 29 & 7.1 \\
\hline & JCo Donuts \& Coffee & 69 & 17.0 \\
\hline & Popolo Coffee & 79 & 19.4 \\
\hline & Doeloe's Coffee & 30 & 7.4 \\
\hline & Ranin Coffee House & 45 & 11.1 \\
\hline & Total & 407 & 100 \\
\hline
\end{tabular}


Table 2. Cross-tabulation of respondent characteristics by coffee shop type

\begin{tabular}{|c|c|c|c|c|c|c|c|}
\hline \multirow[b]{2}{*}{ Characteristics } & \multirow[b]{2}{*}{ Groups } & \multicolumn{4}{|c|}{ Numbers } & \multicolumn{2}{|c|}{ Chi Square } \\
\hline & & $\begin{array}{c}\text { Coffee } \\
\text { Shop Local }\end{array}$ & $(\%)$ & $\begin{array}{c}\text { Coffee } \\
\text { Shop Global }\end{array}$ & $(\%)$ & Value & Sig \\
\hline \multirow{4}{*}{$\begin{array}{l}\text { Average expense } \\
\text { of one visit to the } \\
\text { Coffee Shop }\end{array}$} & $<$ IDR 50,000 & 49 & 28 & 50 & 22 & 2.410 & 0.492 \\
\hline & IDR 50,000 - IDR 150,000 & 106 & 61 & 153 & 66 & & \\
\hline & IDR 150,000 - IDR 300,000 & 18 & 10 & 25 & 11 & & \\
\hline & $>$ IDR 300,000 & 2 & 1 & 4 & 1 & & \\
\hline \multirow{4}{*}{$\begin{array}{l}\text { Frequency of } \\
\text { arrivals to the } \\
\text { Coffee Shop per } \\
\text { week }\end{array}$} & $<2$ times per week & 88 & 50 & 150 & 65 & 11.599 & 0.009 \\
\hline & 2-3 times per week & 68 & 39 & 61 & 26 & & \\
\hline & 3-5 times per week & 18 & 10 & 16 & 7 & & \\
\hline & $>5$ times per week & 1 & 1 & 5 & 2 & & \\
\hline \multirow{6}{*}{$\begin{array}{l}\text { The main reason } \\
\text { to visit the Coffee } \\
\text { Shop }\end{array}$} & Hang out / Relax & 65 & 37 & 98 & 42 & 9.472 & 0.092 \\
\hline & Eat and drink & 8 & 5 & 26 & 11 & & \\
\hline & Doing Lecture/Office Assignments & 21 & 12 & 24 & 10 & & \\
\hline & Looking for inspiration & 16 & 9 & 14 & 6 & & \\
\hline & Socialize with Friends and Relatives & 60 & 34 & 62 & 27 & & \\
\hline & Others & 5 & 3 & 8 & 4 & & \\
\hline \multirow{7}{*}{$\begin{array}{l}\text { The main factor of } \\
\text { visiting the Coffee } \\
\text { Shop }\end{array}$} & Get to know the owner & 6 & 3 & 3 & 1 & 44.497 & 0.000 \\
\hline & Good service & 9 & 5 & 19 & 8 & & \\
\hline & Brand/Image already famous & 5 & 3 & 50 & 22 & & \\
\hline & Easy to reach location & 20 & 11 & 32 & 14 & & \\
\hline & Very Good Coffee Quality & 56 & 32 & 50 & 22 & & \\
\hline & Cozy cafe atmosphere & 76 & 44 & 65 & 28 & & \\
\hline & Others & 3 & 2 & 13 & 5 & & \\
\hline \multirow{4}{*}{$\begin{array}{l}\text { Number of Visits } \\
\text { to the selected } \\
\text { Coffee Shop }\end{array}$} & $<3$ times & 36 & 20 & 25 & 11 & 14.136 & 0.003 \\
\hline & $3-5$ times & 43 & 25 & 39 & 17 & & \\
\hline & $5-10$ times & 22 & 13 & 37 & 16 & & \\
\hline & $>10$ times & 74 & 42 & 131 & 56 & & \\
\hline
\end{tabular}

In terms of how many times most respondents visited both local and global coffee shops, they have visited the chosen coffee shop more than ten times of their record of visiting the coffee shop. It is reasonable to conclude that respondents visited the coffee shop because of the pleasant cafe atmosphere. From a total of 407 respondents, 57 percent chose global coffee shops like Starbucks, The Coffee Bean \& Tea Leaf, and JCO as their preferred coffee shop. In contrast, 43 percent preferred local coffee shops like Popolo, Coffee Doeloe, and Ranin Coffee House. From the Chi-Square value, it can also be inferred that factors such as average expense don't strongly correlate with the respondent choice between local and global coffee shops. At the same time, the frequency of arrivals per week has a strong correlation that affects the respondent's choice to visit local or global coffee shops.

\section{Structural Equation Model (SEM) measurement and analysis}

The maximum likelihood estimation method is used in this study's structural equation engineering model. SEM can estimate the relationship between dependent and independent latent variables. After obtaining a good model, the relationship between variables is examined in order to demonstrate the validity of the theory that underpins it. Figure 2 shows arrow relationship between $\mathrm{e} 1 \longleftrightarrow \longrightarrow \mathrm{e} 3$, and $\mathrm{e} 2 \longleftrightarrow \longrightarrow \mathrm{e} 4$. The relationship indicates that the error in the social media marketing variable has a relationship, which can be demonstrated by the calculation results of modification indices with values greater than 10,000 on AMOS. 
Figure 2 SEM analysis of the initial model framework Measurement in this model used to describe the relationship between the indicator and latent variable. After respecification process, relationship marketing has five indicator variables, social media marketing has four indicator variables, costumer trust has has four variables, and repurchase intention has two indicator variables. Another latent variables are customer trust and repurchase intention. They acted as endogen latent variables in this research. Customer trust has four indicator variables and after respecification process, repurchase intention only has two indicator variables. The influence of dominant indicator variables can be analyzed using the value of factor loading from each indicator variables. It measured by measure the standardized estimates value using IBM SPSS AMOS version 20. The result of factor loading of each latent variables and their indicator variables described by Table 3.

\section{Model Fit Test}

The model fit test results show that the chi-square value is small, with a value of 633,909 , indicating that the model is very close to good. According to Table 4, in the initial model test, all criteria such as RMSEA, CMIN/DF, CFI, and Chi-square fall into the fit category.
Because they are close to the critical value or the set cut-off value, some of the criteria values in the model are still acceptable even though they do not produce the same specific results as the cut-off value.

\section{Determine the relationship between variables}

Causality analysis was used to determine the causal relationship between variables in this study's SEM model. Table 5 displays the results of the overall T-test of respondents at a probability of $5 \%$ based on IBM SPSS AMOS version 20 output results. The T-test results in Table 5 show that three variables, namely social media marketing, relationship marketing, and dining atmosphere, significantly affect trust in coffee shop consumers in the city of Bogor. With a positive CR (critical ratio) value of 6.808 , the calculation results show that the relationship marketing variable has the most significant influence on customer trust. The higher the CR value, the more significant the influence of a variable on other variables. Relationship marketing had the greatest impact on customer trust because the relationship between coffee shop employees and customers made consumers feel at ease, and they will continue to trust the coffee shop for their coffee consumption needs or simply to hang out at the coffee shop.

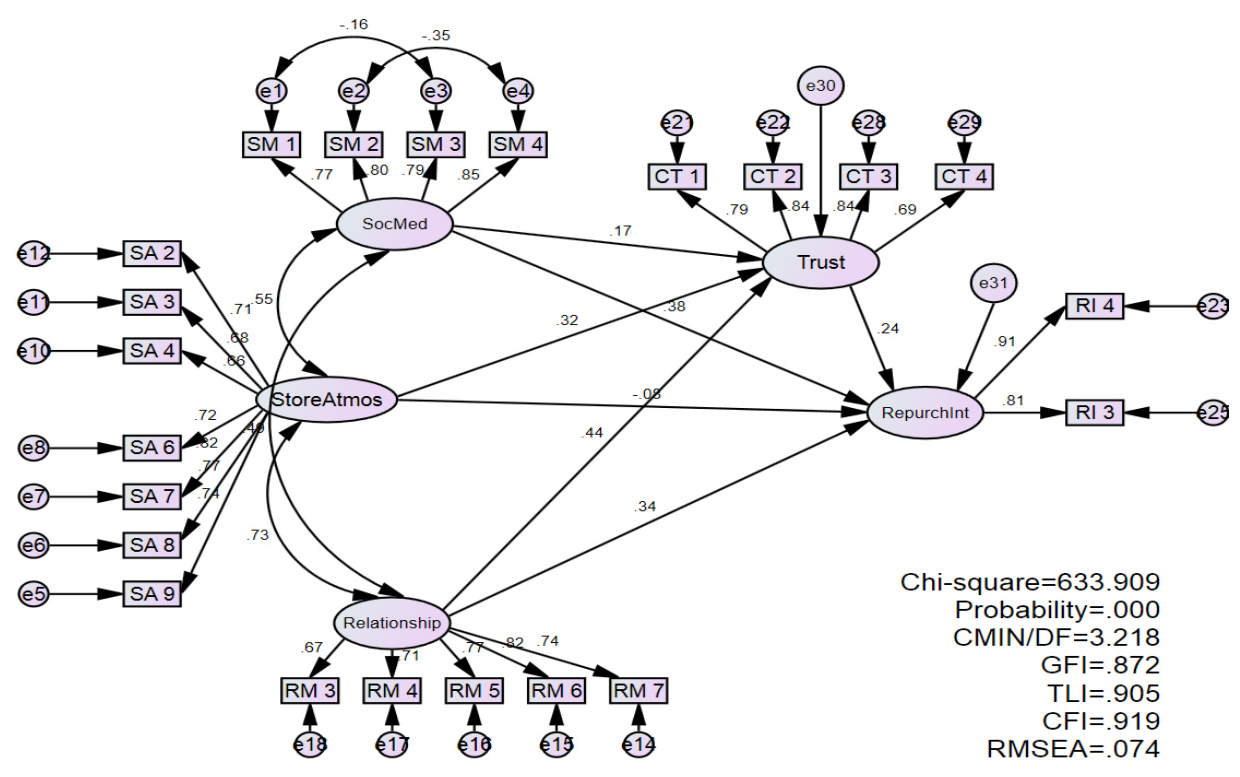

Figure 2. SEM analysis of the initial model framework 
Table 3. Factor loading of measurement items

\begin{tabular}{|c|c|c|}
\hline Construct & Item Used & $\begin{array}{l}\text { Factor } \\
\text { Loading }\end{array}$ \\
\hline \multirow{5}{*}{$\begin{array}{l}\text { Relationship } \\
\text { marketing }\end{array}$} & Staff and waiter treat the customer as their loyal costumer (RM 3) & 0.67 \\
\hline & Staff and waiter well treated the customer (RM 4) & 0.71 \\
\hline & $\begin{array}{l}\text { Staff and waiter always giving the well and right information about available product menus dan } \\
\text { promos to the customer (RM 5) }\end{array}$ & 0.77 \\
\hline & Staff and waiter directly apologize if there are any mistakes (RM 6) & 0.82 \\
\hline & $\begin{array}{l}\text { Staff and waiter responded to complaints, critics, and advices from the customer very well (RM } \\
\text { 7) }\end{array}$ & 0.74 \\
\hline \multirow{4}{*}{$\begin{array}{l}\text { Social } \\
\text { media } \\
\text { marketing }\end{array}$} & I use social media to find out the information about this coffee shop (SM 1) & 0.77 \\
\hline & I upload photo and check in the place in social media when I visit this coffee shop (SM 2) & 0.80 \\
\hline & $\begin{array}{l}\text { I followed many same kind of café in my social media to add the information about coffee shop } \\
\text { (SM 3) }\end{array}$ & 0.79 \\
\hline & Because the information from social media, I visit to this coffee shop (SM 4) & 0.85 \\
\hline \multirow{6}{*}{$\begin{array}{l}\text { Dining } \\
\text { Atmosphere }\end{array}$} & Building design of the coffee shop is very interesting and make me want to visit it (DA 2) & 0.71 \\
\hline & $\begin{array}{l}\text { The condition of indoor and outdoor places at the coffee shop are always neat and clean, and make } \\
\text { me feel comfortable at the coffee shop (DA 3) }\end{array}$ & 0.68 \\
\hline & $\begin{array}{l}\text { The waiter and barista at the coffee shop make me feel comfortable and want to hang out for a long } \\
\text { time (DA 4) }\end{array}$ & 0.66 \\
\hline & $\begin{array}{l}\text { Layout and storefront to keep food menu at the coffee shop very systematic and neat, make me } \\
\text { interests to buy (DA 6) }\end{array}$ & 0.72 \\
\hline & $\begin{array}{l}\text { Room layout of the coffee shop is neat and comfortable and make me want to stay for a long time } \\
\text { (DA 7) }\end{array}$ & 0.74 \\
\hline & Room layout of the coffee shop make me want to visit it (DA 9) & 0.72 \\
\hline \multirow{4}{*}{$\begin{array}{l}\text { Customer } \\
\text { trust }\end{array}$} & I believe this coffee shop is fair and honest (CT 1) & 0.79 \\
\hline & Staff of this coffee shop can maintain a good realationship with me (CT 2) & 0.84 \\
\hline & I believe to always trust this coffee shop (CT 3) & 0.84 \\
\hline & Products and services delivered in this coffee shop meet my expectation (CT 4) & 0.69 \\
\hline \multirow{2}{*}{$\begin{array}{l}\text { Repurchase } \\
\text { intention }\end{array}$} & I want to routinely visit coffee shop minimally two times per week (RI 3) & 0.81 \\
\hline & $\begin{array}{l}\text { I intent to do repurchase product at this coffee shop despite have more interesting offer from other } \\
\text { coffee shop (RI 4) }\end{array}$ & 0.91 \\
\hline
\end{tabular}

Table 4. The results of the initial model's goodness of fit test

\begin{tabular}{lcccc}
\hline & Criteria & $\begin{array}{c}\text { Cut-off value } \\
\text { (critical value) }\end{array}$ & Results & Information \\
\hline Chisquare & Expected small & 633.909 & $\mathrm{fit}$ & \\
RMSEA & $<0.08$ & 0.074 & $\mathrm{fit}$ & $\mathrm{fit}$ \\
CMIN/DF (the minimum sample discrepancy function/degree of freedom) & $<5$ & 3.218 & $\mathrm{fit}$ \\
CFI (comparative fit index) & $>0.90$ & 0.919 & $\mathrm{fit}$ \\
GFI (goodness of fit index) & $>0.90$ & 0.872 & Moderate fit \\
TLI (Tucker-Lewis index) & $>0.90$ & 0.905 & $\mathrm{fit}$ \\
\hline
\end{tabular}

The customer trust variable had a significant influence on customer repurchase intention; the findings of this study were consistent with research (Unjaya and Santoso, 2015) that found trust to have a significant and positive influence on customer repurchase intention. While the dining atmosphere variable, the calculation results show that dining atmosphere do not have a direct significant effect on repurchase intention, but must be filtered through a new customer trust variable that did. The findings of this study differed from those of previous studies conducted by (Sarah, 2017), indicating that dining environment has a significant and positive influence on repurchase intention. 
Table 5. The results of the initial model's causality test

\begin{tabular}{lccccc}
\hline Endogenous Latent Var & & Exogenous Latent Var & CR & T- table & Information \\
\hline Trust & $\leftarrow$ & SocMed & 4.682 & 1.96 & Significantly influential \\
Trust & $\leftarrow$ & Relationship & 6,808 & 1.96 & Significantly influential \\
Trust & $\leftarrow$ & Atmosphere & 4,536 & 1.96 & Significantly influential \\
RepurchIn & $\leftarrow$ & SocMed & 7,419 & 1.96 & Significantly influential \\
RepurchIn & $\leftarrow$ & Trust & 2.878 & 1.96 & Significantly influential \\
RepurchIn & $\leftarrow$ & Relationship & 4.358 & 1.96 & Significantly influential \\
RepurchIn & $\leftarrow$ & Atmosphere & -.980 & 1.96 & No significant effect \\
\hline
\end{tabular}

\section{Social Media Influence by Local \& Global Coffee Shop category}

Furthermore, the researchers created the second and third SEM models by dividing the total number of respondents by the type of coffee shop they preferred. The second and third models were created to determine whether there is a difference in the calculation results and whether there is a difference in the effect of research variables on local and global coffee shops respondents. According to the findings of the causality analysis (Table 6), there were two variables that significantly influence trust in local coffee shop consumers in Bogor City: social media marketing and relationship marketing.

The findings show that the relationship marketing variable had the most influence in creating customer trust for local coffee shop customers in the city of Bogor. This can be interpreted as the relationship that exists between the coffee shop and the customer at the local coffee shop making the customer trust the coffee shop. Furthermore, at the local coffee shop, all coffee shops are owned by individuals, whose owners frequently went directly to visit customers and sometimes served customers, establishing good relationships. Customers' trust and respect were directly increased as a result of the efforts. This is consistent with the belief of Al-Hersh and Saaty (2014) that in order to win the hearts of customers, businesses must create customer satisfaction and trust.

Meanwhile, the dining atmosphere variable did not significantly create customer trust for local coffee shop customers. Similarly, customer trust could not mediate the relationship between dining atmosphere and repurchase intention among local coffee shop customers. This means that for local coffee shop customers, the coffee shop's social media marketing and relationship marketing can significantly increase customer trust
(Ndubisi, 2017). However, just because a customer had trusted the coffee shop does not mean that the customer will make repeat purchases. Customer repurchase at a local coffee shop in Bogor City will be significantly influenced by relationship marketing and social media marketing without the need for customer trust. It can be seen at a local coffee shop that the dining atmosphere had no significant effect on both customer trust and repurchase intention. Cleanliness and tidiness at local coffee shops that are not maintained make consumers unable to trust the coffee shop directly, and there is no chance that consumers will make repeat purchases due to the coffee shop's dining atmosphere.

In addition, the following Tables 7 shows the direct and indirect relationships between variables in respondents from local coffee shops. The table shows that the dining atmosphere had no direct influence on customer trust because the result of the analysis was -0.38 , indicating a negative influence. Relationship marketing variables had a large direct influence on customer trust, and social media marketing directly influenced customer trust, though not as large as relationship marketing. Meanwhile, the dining atmosphere variable directly affected repurchase intention, but only with a very small value of 0.04 and had a negative indirect effect on repurchase intention. Relationship marketing and social media marketing both had the same direct impact on repurchase intention. Relationship marketing and social media marketing had an indirect impact on repurchase intention as well.

Unlike the causality test results at the local coffee shop, the global coffee shop demonstrates that the three exogenous latent variables, namely social media marketing, relationship marketing, and dining atmosphere, significantly affected customer trust for global coffee shop customers in Bogor City. The dining atmosphere was the most influential variable on customer trust. It is possible to conclude that most 
customers at global coffee shops trust the coffee shop because of its comfortably and convincing atmosphere. This is consistent with the frequency analysis results on the respondents' characteristics, which show that a comfortable café atmosphere was the most important factor for the majority of respondents visiting the coffee shop.

Meanwhile, the global coffee shop causality analysis found that only two variables, social media marketing and customer trust, significantly influence customer repurchase intention. Customer repurchase interest may arise as a result of the global coffee shop's excellent social media marketing. The majority of respondents in this study were millennials, which technology and the internet are inextricably linked in their daily lives. As a result, social media marketing has proven extremely effective in the modern era because it can generate customer repurchase interest. The findings of this study on global coffee shops support the findings of Arief and Millanyani (2015). They explain that social media marketing has a significant impact on consumer repurchase interest through various forms of offerings and the formation of an understanding of the products being sold. While the relationship marketing and dining atmosphere variables did not significantly affect repurchase intention, the effect will be significant once customer trust is established. In other words, if customer trust is established first, the dining atmosphere at a global coffee shop will prompt repeat purchases.

Table 7 shows that the dining atmosphere at a global coffee shop had the most direct and significant influence on customer trust. Compared to the relationship marketing and social media marketing variables, the Dining atmosphere had a statistically significant result of 0.45 . The variables of relationship marketing and social media marketing had a direct impact on the customer. Meanwhile, the dining atmosphere variable had no direct effect on repurchase intention. Because the analysis resulted in a negative value, but it had a fairly large indirect effect of 0.24 . The indirect effect of the relationship marketing variable on repurchase intention was greater than the direct effect.

\section{Managerial Implications}

Based on the factor load value, the most important and significant variables on customer trust and repurchase intention of local and global coffee shop customers will be prioritized in this discussion. Based on the research findings, both local (Popolo coffee, Doeloe coffee, Ranin Coffee) and global (Starbucks Coffee, The Coffee Bean \& Tea Leaf, Jco Donuts \& Coffee). Coffee shops can apply Segmentation, Targeting, and Positioning (STP) concepts from Kotler (1996) that define needed strategic marketing related to what kind of value is delivered to customers.

Segmentation:Coffee shops can market the segmentation market to outgoing people who like to travel and hang out with their friends. They will become more comfortable and enjoy places where they can spend much time with their friends and interesting to visit as they have artistic features and unique layouts. Service from the coffee shop staff also maintains an important role to keep a customer loyal to the coffee shop.

Table 6 . Causality analysis by coffee shop category

\begin{tabular}{|c|c|c|c|c|c|c|c|c|c|c|}
\hline \multirow{2}{*}{ Latent Endo } & & \multirow{2}{*}{ Latent Exo } & \multicolumn{2}{|c|}{ Estimate } & \multicolumn{2}{|c|}{ Critical Ratio } & \multicolumn{2}{|c|}{ P-value } & \multicolumn{2}{|c|}{ Annotation } \\
\hline & & & Local & Global & Local & Global & Local & Global & Local & Global \\
\hline Trust & $\leftarrow$ & SocMed & 0.214 & 0.204 & 2,609 & 3.656 & $* * *$ & $* * *$ & $\sqrt{ }$ & $\sqrt{ }$ \\
\hline Trust & $\leftarrow$ & Relationship & 0.778 & 0.417 & 4.389 & 5.745 & $* * *$ & $* * *$ & $\sqrt{ }$ & $\sqrt{ }$ \\
\hline Trust & $\leftarrow$ & Atmosphere & -.380 & 0.450 & -.235 & 5.793 & 0.814 & $* * *$ & & $\sqrt{ }$ \\
\hline RepurchIn & $\leftarrow$ & SocMed & 0.428 & 0.237 & 4.291 & 3.265 & $* * *$ & $* * *$ & $\sqrt{ }$ & $\sqrt{ }$ \\
\hline RepurchIn & $\leftarrow$ & Trust & 0.267 & 0.541 & 1,916 & 2.660 & 0.055 & $* * *$ & & $\sqrt{ }$ \\
\hline RepurchIn & $\leftarrow$ & Relationship & 0.431 & 0.182 & 1974 & 1,592 & 0.048 & 0.111 & $\sqrt{ }$ & \\
\hline RepurchIn & $\leftarrow$ & Atmosphere & 0.045 & -.101 & -.275 & -.835 & 0.783 & 0.404 & & \\
\hline
\end{tabular}

Note: use alpha $5 \% ; \sqrt{ }$ (significant influence or relationship) 
Table 7. Standardized effects of local and global coffee shop

\begin{tabular}{lcccccccc}
\hline & \multicolumn{3}{c}{ Local Coffee Shops } & \multicolumn{5}{c}{ Global Coffee Shops } \\
\cline { 2 - 9 } & Atmosphere & Relationship & $\begin{array}{c}\text { Social } \\
\text { Media }\end{array}$ & Trust & Atmosphere & Relationship & $\begin{array}{c}\text { Social } \\
\text { Media }\end{array}$ & Trust \\
\hline Indirect effects & & & & & & & & \\
Trust & 0.000 & 0.000 & 0.000 & 0.000 & 0.000 & 0.000 & 0.000 & 0.000 \\
$\begin{array}{l}\text { Repurchase Intention } \\
\text { Direct effects }\end{array}$ & -0.010 & 0,144 & 0.057 & 0.000 & 0,169 & 0,156 & 0,076 & 0.000 \\
Trust & -0.380 & 0,540 & 0,149 & 0.000 & 0,313 & 0,290 & 0,142 & 0.000 \\
\hline Repurchase Intention & 0.045 & 0,299 & 0,297 & 0,185 & -0.101 & 0,126 & 0,165 & 0,376 \\
\hline
\end{tabular}

Targeting: Potential target customer that needed to be considered by the coffee shop is people who have a certain lifestyle related to the consumer behaviour in the coffee shop. From this study, it can be inferred that average expense doesn't have a strong correlation in customer decision to choose between local and global coffee shops, so it's must be another factor that influences them. The factor is related to the customer's lifestyle. People with a certain lifestyle usually have high dignity to keep their lifestyle, so the coffee shop must take this opportunity to make them loyal and repurchase intention.

Positioning: Based on the product specification by Kotler (1994), coffee is a consumer good, but it does not belong to an essential product to consume. In other words, people do not need to consume coffee in their daily activities. To maintain customers' loyalty, coffee shops must analyze their psychological aspects related to the correlation between the product and their personality, so the product can indirectly and directly define the customer. The coffee shop can make the positioning to their product, not limited to consume the coffee but to define who wants to express themselves as highly taste person (elegant person) or a creative person. People enjoy something such as art to understand that people who consume coffee define their own identity or personality just by seeing them hang out at the coffee shop.

\section{CONCLUSIONS AND RECOMMENDATIONS}

\section{Conclusions}

Consumer behavior in making purchases has also changed along with the development of culture and lifestyle. Currently the lifestyle of consuming coffee shifts from consuming coffee at home to visiting coffee shops. Based on the findings, relationship marketing and social media marketing have a direct and significant effect on the repurchase intention and customer trust of local coffee shop customers in Bogor City. Meanwhile, the dining atmosphere has no effect on customer trust or repurchase intention among local coffee shop customers in the city of Bogor. Social media marketing, combined with relationship marketing, has the greatest influence on repurchase intention at a local coffee shop. Relationship marketing, on the other hand, had the greatest influence on customer trust in local coffee shops.

\section{Recommendations}

Coffee shops should improve the variables that have a significant impact on repurchase intention and customer trust. In addition, there are two variables to consider for the coffee shop to increase repurchase intention and customer trust. The first variable is social media marketing. To increase repurchase intention from the customer, a coffee shop can make a campaign to its customer to post their activities at the coffee shop on their social media and share it with other people. The best and most unique post will be given a reward from the coffee shop such as discount, exclusive promo, free product etc. This strategy will gradually increase engagement between customers and coffee shops, make other people aware of the brand from the coffee shop itself, and impact the repurchase intention from the customer in the future. The second variable to consider is relationship marketing, which relies on how the coffee shop's staff treat the customer well and build trust or loyalty. The coffee shop can make basic service procedures to treat the customer like "a king or queen". To do this, the coffee shops make a basic service procedure such as greeting the customer warmly, being proactive from their requests, being honest with the service product, giving a recommendation product based on the customer's profile, and paying attention to their complaints or advice. Well-serviced costumer 
can feel happy and satisfied that will impact their trust in the coffee shop.

This study is limited to six coffee shops in Bogor City. Starbucks Coffee Botani Square, The Coffee Bean \& Tea Leaf Botani Square, JCo Donuts \& Coffee Botani Square, Popolo Coffee, Ngopi Doeloe, and Rumah Kopi Ranin. It is recommended to conduct the research not only limited to some coffee shops in one location but also in another location to make a variety of the data. Data collection in this study is just three months of the research process, so the data can only be generalised during that period.

\section{REFERENCES}

Al-Hersh AM, Saaty AS. 2014. The impact of customer relationship marketing on customer satisfaction of the Arab bank services. International Journal of Academic Research in Business and Social Sciences 4(5): 67-100. https://doi.org/10.6007/ IJARBSS/v4-i5/824

Arief GM, Millanyani H. 2015. Pengaruh social media marketing melalui instagram terhadap minat beli konsumen sugar tribe. eProceedings of Management 2(3).

Ashbeck H. 2020. Coffee Shop Communication: Social Media \& Engagement. Madison: Division of Communication, University of WisconsinStevens Point

Chinomona R, Dubihlela D. 2014. Does customer satisfaction lead to customer trust, loyalty and repurchase intention of local store brands? The case of Gauteng Province of South Africa. Mediterranean Journal of Social Sciences 5(9): 23-32.

Fannani SI, Najib M, Sarma M. 2020. The Effect of Social Media Toward Organic Food Literacy and Purchase Intention with AISAS Model. Jurnal Manajemen dan Agribisnis 17(3): 285-294. https://doi.org/10.17358/jma.17.3.285

Hellier PK, Geursen GM, Carr RA, Rickard JA. 2003. Customer repurchase intention: A general structural equation model. European journal of marketing 37(11/12):762-1800. https://doi. org/10.1108/03090560310495456

Husnain M, Toor A. 2017. The impact of social network marketing on consumer purchase intention in Pakistan: Consumer engagement as a mediator. Asian Journal of Business and Accounting
10(1):167-199.

Jang YJ, Kim WG, Lee HY. 2015. Coffee shop consumers' emotional attachment and loyalty to green stores: The moderating role of green consciousness. International Journal of Hospitality Management 44:146-156. https:// doi.org/10.1016/j.ijhm.2014.10.001

Kerlinger. 2006. Asas-asas Penelitian Behavioral. Yogyakara: Gadjah Mada University Press.

Kotler P, Amstrong G. 2008. Prinsip - Prinsip Pemasaran, edisi 12. Jakarta: Erlangga.

Kotler P. 1996. Principle of Marketing, edisi 7. New Jersey: Prentice Hall International, Inc.

Kotler P. 2008. Manajemen Pemasaran, edisi 11. Jilid 2, Edisi Bahasa Indonesia. Jakarta: Indeks.

Levy, Weitz. 2001. Retailing Management, edisi 4. New York: Mc.Grawhill.

Ndubisi NO. 2017. Relationship marketing and costumer loyalty. Marketing Intelligence \& Planning 25: 98-105. https://doi. org/10.1108/02634500710722425

Nawaz A, Abbas G, Javed MF, Mughal N, Nabeel M. 2015. Impact of social media and voice of customer (voc) in decision making process an empirical study of higher education institutions of Pakistan. Middle-East Journal of Scientific Research 23(6):1069-1075.

Oldenburg R. 1999. The Great Good Place: Cafes, Coffee Shops, Bookstores, Bars, Hair Salons, And Other Hangouts At The Heart Of A Community. Da Capo Press.

Phillips J, Noble SM. 2007. Simply captivating: Understanding consumers' attitudes toward the cinema as an advertising medium. Journal of Advertising 36(1): 81-94. https://doi. org/10.2753/JOA0091-3367360106

Rina AW. 2014. Analisis faktor-faktor yang mempengaruhi purchase intention melalui social media marketing terhadap produk frozen yogurt sour sally di Surabaya. Jurnal Gema Aktualita 3(2): 37-44.

Sarah N. 2017. Pengaruh store atmoshpere, lokasi, dan harga terhadap repurchase intention (Studi kasus pada konsumen Carrefour DP Mall Semarang) [desertasi]. Semarang: Fakultas Sosial dan Ilmu Politik, Universitas Diponegoro.

Sheth, Jagdish N, Mittal B. 2004. Customer Behaviour: Managerial Perspective. Ed. ke-2. Singapore: Thomson.

Sugiyono. 2013. Metode Penelitian Kuantitatif, Kualitatif dan $R \& D$. Bandung: Alfabeta. 
Torga GN, Spers EE. 2020. Perspectives of global coffee demand. In Coffee Consumption and Industry Strategies in Brazil (pp. 21-49). Woodhead Publishing.

Unjaya GD, Santoso L. 2015. Analisis pengaruh satisfaction, trust, dan commitment terhadap repurchase intentions pelanggan tetap hotel Raden Wijaya Mojokerto. Jurnal Hospitalitity dan Manajemen Jasa 3(2):291-303.

Waxman L. 2006. The coffee shop: Social and physical factors influencing place attachment. Journal of Interior Design 31(3): 35-53. https://doi. org/10.1111/j.1939-1668.2006.tb00530.x

Wen SL, Yazdanifard R. 2014. Relationship marketing vs. internet marketing which one contribute to gain higher level of consumer loyalty. Global Journal of Management and Business Research 14(7): 41-47.

Yousafzai SY, Pallister JG, Foxall GR. 2003. A proposed model of e-trust for electronic banking. Technovation 23(11) :847-860. https://doi. org/10.1016/S0166-4972(03)00130-5 